\title{
GEOCHEMICAL CHARACTERISTICS OF A LATERITE: THE JURASSIC ZAN DEPOSIT, IRAN
}

\author{
Ali ASGHAR CALAGARI ${ }^{1)}$ *, Fatemeh KANGARANI FARAHANI ${ }^{1)}$ and Ali ABEDINI ${ }^{2)}$ \\ ${ }^{1)}$ Department of Earth Sciences, Faculty of Natural Sciences, University of Tabriz,5166616471 Tabriz, Iran \\ (Tel: +98-411-3392699; Fax: +98-41-33392703) \\ 2) Department of Geology, Faculty of Sciences, University of Urmia, 57153165, Urmia, Iran
}

(Tel: +98-441-2972134; Fax: +98-44-32753172)

*Corresponding author's e-mail: calagaria@yahoo.com and calagari@tabrizu.ac.ir

\begin{tabular}{l} 
ARTICLE INFO \\
\hline Article history: \\
Received 25 October 2014 \\
Accepted 13 December 2014 \\
Available online 4 February 2015 \\
\hline Keywords: \\
Geochemistry \\
Laterite \\
Absolute weathering index \\
Parent rock \\
Zan \\
Iran
\end{tabular}

\section{ABSTRACT}

The Zan lateritic deposit is located in $\sim 25 \mathrm{~km}$ southeast of Damavand, Tehran province, Iran. This deposit was developed as stratiform at the base of Shemshak (sandstone and shale) Formation of Jurassic age. Mineralogical data shows that rock-forming minerals in this deposit include kaolinite, diaspore, hematite, goethite, anatase, boehmite, siderite, rutile, quartz, titanomagnetite, zircon and pyrite. The values of absolute weathering index calculated on the assumption of $\mathrm{Th}$ as an immobile element indicate that lateritization processes at the Zan were accompanied by enrichment of elements like $\mathrm{Al}, \mathrm{Fe}, \mathrm{Zr}, \mathrm{Nb}, \mathrm{Ni}, \mathrm{Cr}, \mathrm{Co}, \mathrm{Y}, \mathrm{V}$, and REEs and by leaching-fixation of elements such as $\mathrm{U}, \mathrm{Mn}, \mathrm{Sr}, \mathrm{Ba}$, and $\mathrm{Ca}$. Combination of the data obtained from mineralogical and geochemical investigations reveals that $\mathrm{pH}$ variation of weathering solutions, oxidation potential, adsorption, presence of organic matters, preferential sorption by metallic oxides, presence in resistant minerals and fixation in neomorph phases played prominent role in distribution of elements in the Zan lateritic deposit. With considering of correlation coefficients among elements, the minerals such as zircon and rutile can be regarded as potential hosts for REE in the ores. Palaeogeography evidence as well as geochemical indices like $\mathrm{TiO}_{2} / \mathrm{Al}_{2} \mathrm{O}_{3}$ and $\mathrm{Eu} / \mathrm{Eu}^{*}$ anomaly suggests that this deposit is a weathering product of basalt.

\section{INTRODUCTION}

Chemical weathering of the rocks is one of important surficial process that causes geochemical redistribution of elements and is controlled by various factors such as topography, parent rock type, climate conditions, plant and biological activities (Bardossy, 1982; Bogatyrev et al., 2009). Physico-chemical characteristics like $\mathrm{Eh}$ and $\mathrm{pH}$ are determinative factors for the type of behavior of elements in weathering environment (Yalcin and Ilhan, 2008, 2013; Calagari and Abedini, 2007; Abedini and Calagari, 2013a; Gu et al., 2013; Li et al., 2013; Giorgis et al., 2014; Berger et al., 2014). The main problem concerning the laterites that were not developed in alumino-silicate rocks is to find the parent rocks and to get a proper perception of their mode of formation. In many researches done so far various methods were proposed by workers to solve this problem. Some are based upon using the immobile elements like $\mathrm{Ti}, \mathrm{Zr}$, $\mathrm{Hf}, \mathrm{Ta}, \mathrm{Cr}$, and $\mathrm{Nb}$ (Kurtz et al., 2000; Calagari et al., 2010; Abedini and Calagari, 2013a, b, c; Hanilçi, 2013) while others apply the pattern of rare earth elements (REEs) along with their anomaly indices (e.g., Eu anomaly) (Nyakairu et al., 2001; Mameli et al., 2007; Karadağ et al., 2009; Liu et al., 2010).

Depositional cessation during Permian, PermoTriassic, Triassic, Jurassic, and middle Cretaceous brought about development of many lateriticbauxitic horizons in various parts of Alborz and Zagros mountain chains as well as in Central and northwestern zones of Iran. The lateritic and bauxitic horizons of many parts of Iran have been mineralogically, geochemically, and genetically investigated by various workers (Esmaeily et al., 2010; Calagari et al., 2010; Zarasvandi et al., 2010, 2012; Abedini and Calagari, 2013a, b, c; Abedini and Calagari, 2014; Abedini et al., 2014). Temporally, the lateritic and bauxitic deposits of Alborz mountain chain were widely and principally developed during Triassic and Jurassic and to lesser extent during Permo-Triassic period. The Zan laterite is one of the Central Alborz lateritic deposits that is located $\sim 25 \mathrm{~km}$ southeast of Damavand (Tehran province), Iran. However, no investigation on geochemical characteristics of this deposit was carried out previously up to 2012. In 2012, relatively comprehensive studies on field relations, mineralogy, texture, and geochemistry of this deposit were done by the authors. The present study uses field relations, petrography, and geochemistry (mass change geochemical techniques and correlation coefficients) to consider the parental affinity and the factors affecting the distribution of major, minor, trace, and rare earth elements during lateritization processes at Zan. 


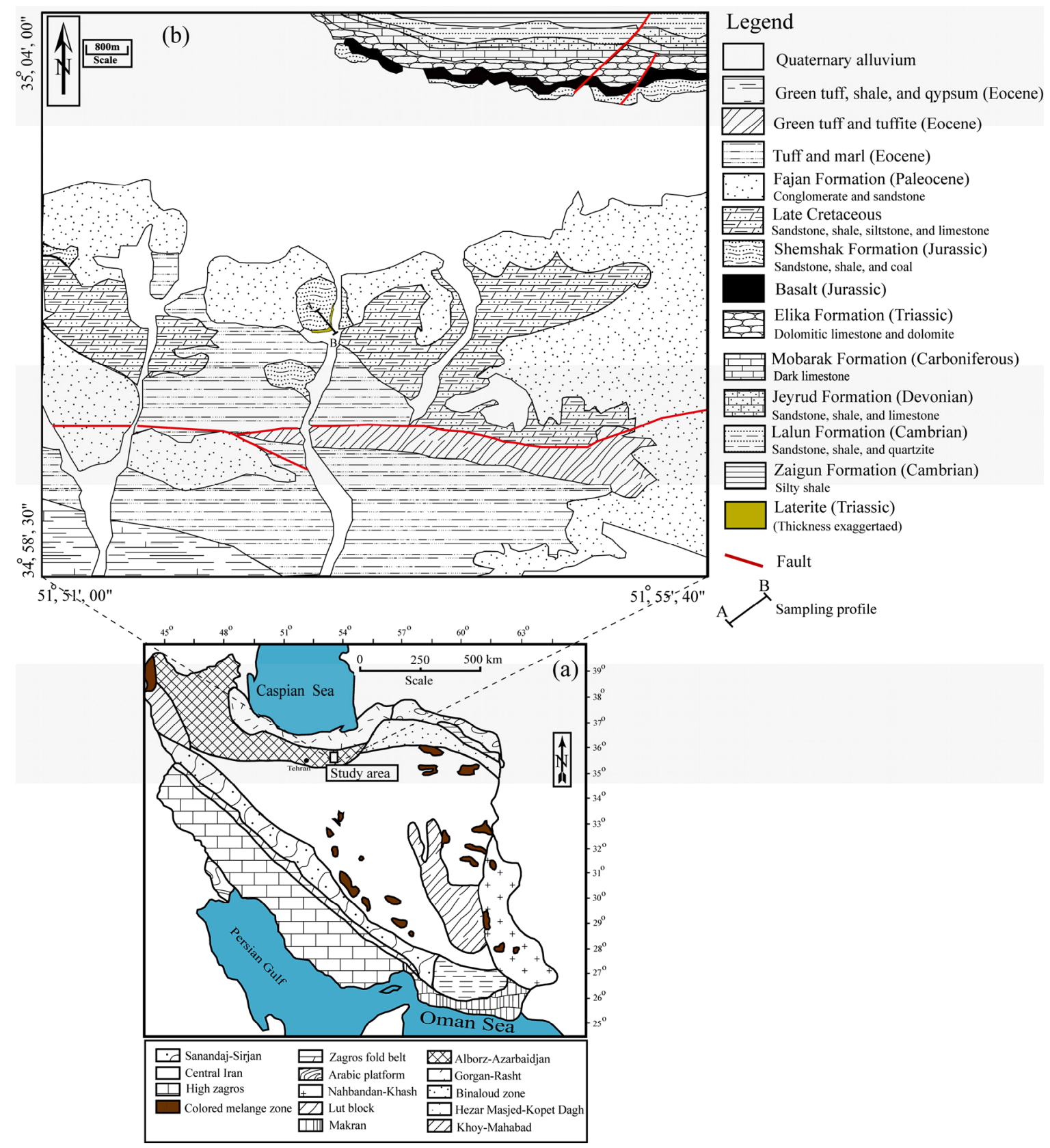

Fig. 1 The position of the studied area on the map of structural zones of Iran (Nabavi, 1976). (b) Geologic map of the studied area (modified after Amini and Khalatbari, 1972) on which the position of the Zan lateritic horizon is shown.

\section{GEOLOGY}

The studied lateritic deposit is a part of the Irano-Himalayan karst bauxite belt. The study area, based upon structural divisions of Iran (Nabavi, 1976) lies in the Alborz-Azarbaidjan zone (Fig. 1a). Zaigun (silty shale), Lalun (shale and sandstone), and Mila (dolomite and limestone) Formations are the oldest sedimentary rocks, which are of Cambrian age. Ordovician-Silurian and early Devonian sediments do not crop out in this area. The Mila Formation is disconformably overlain by the Jeyrud (sandstone, shale and limestone) Formation of upper Devonian age that in turn is covered by the Mobarak (calcareous shale and carbonate) Formation. There was a depositional cessation during middle to Upper Carboniferous period (Aghanabati, 2004). Lower Permian sandstone and shales are overlain disconformably by the Elika (limestone and dolomite) Formation, which is of early Triassic age. There was depositional cessation during middle and upper Triassic and no sedimentation was occurred during this period. Erosion and weathering during this period of regression caused the development of karstic topography on the top of the Elika Formation. Basaltic 
rocks cover the Elika Formation in the study area as well as in many other places in the Alborz mountain chain (Aghanabati, 2004). In early Jurassic, continental-lagoonal sediments of Shemshak (coalbearing shale and sandstone) Formation were formed. The Zan lateritic horizon lies at the basal section of the Shemshak Formation. The lithological sequence continues with Fajan (conglomerate and sandstone) Formation of Paleocene, Karaj (tuff, marl, and shale) Formation, which is of Eocene age. These are followed by Quaternary alluviums (Amini and Khalatbari, 1972; Fig. 1b).

The Zan lateritic horizon occurs as stratiform layer trending NE-SW and extends about $1 \mathrm{~km}$ with variable thickness ranging from 5 to 15 meters (Fig. 1b). A selected profile shows ten lithologic layers defined by various colors. They are, from the bottom to the top, (1) brown (BL), (2) red (RL), (3) yellow (YL), (4) layered gray (LGL), (5) olive gray (OGL), (6) greenish gray (GGL), (7) reddish gray (RGL), (8) dark gray (DGL), (9) bluish gray (BGL), and (10) gray (GL) (Fig. 2). The horizon and the enclosing rocks were affected by structural forces and display fracturing and brecciation in almost all units within the horizon.

\section{METHODS}

Field work was carried out in spring 2012. About 30 samples from various units across lateritic horizon and the enclosing rocks were taken. After mesoscopic examination, six samples of lateritic horizon were selected to be analyzed by X-ray diffraction (XRD) (SIEMENS Diffractometer, model D-5000, CuK $\alpha$ radiation, fixed graphite chromators, voltage $40 \mathrm{kV}$, current $40 \mathrm{~mA}$, scanning speed $2^{\circ}$ per minute, scan range $2-70^{\circ}$ ) for identification of unknown mineral phases at Geological Survey of Iran. For identification of clay minerals, the samples were treated with $\mathrm{KCl}$ (at $550{ }^{\circ} \mathrm{C}$ ), $\mathrm{MgCl}_{2}$, and ethylene glycol. Complementary investigations on mineralogy of the ores were carried out by scanning electron microscopy (SEM; a XLC Philips at Amirkabir University in Tehran). For determination of chemical composition, ten representative samples taken from the ores across the studied profile were selected and chemically analyzed at ACME laboratories in Canada (analytic code 4A4B) by using ICP-ES (for major and minor oxides) and ICP-MS (for trace and rare earth elements) methods. Loss on ignition (LOI) values were measured by weighing the samples (3 to 4 grams each) before and after five minutes of heating at 1040$1060{ }^{\circ} \mathrm{C}$. Detection limit for major and minor oxides is $0.01 \mathrm{wt} \%$ (except for $\mathrm{Fe}_{2} \mathrm{O}_{3}, \mathrm{Cr}_{2} \mathrm{O}_{3}$, and LOI which are $0.04,0.002$, and $0.1 \mathrm{wt} \%$, respectively). Detection limit for trace elements is $0.1 \mathrm{ppm}$ and for rare earth elements $0.05 \mathrm{ppm}$ (except for $\mathrm{Ba}, \mathrm{Ga}, \mathrm{Sr}, \mathrm{Pr}, \mathrm{Nd}, \mathrm{Eu}$, Ho, Er, and Tm which are 1, 0.5, 0.5, 0.02, 0.3, 0.02, $0.01,0.02,0.03$, and 0.01 , respectively). For determination of REE values, about 0.2 gram of each sample is treated with metaborate and lithium

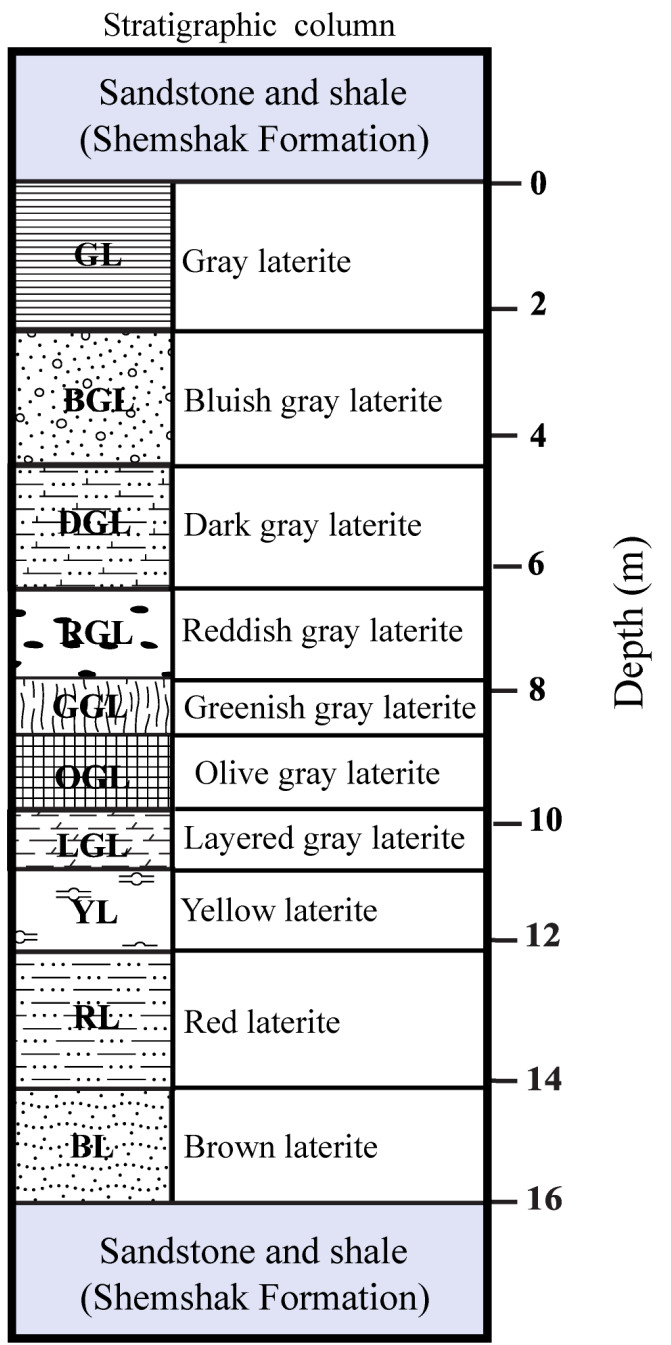

Fig. 2 Stratigraphic column across a selected profile in the Zan lateritic horizon.

tetraborate and then is dissolved in $\mathrm{HNO}_{3}$ acid. The results of the chemical analyses are presented in Table 1.

\section{RESULTS AND DISCUSSION}

\subsection{MINERALOGY AND CHEMICAL COMPOSITION}

$\mathrm{X}$-ray diffraction (XRD) analyses show that the Zan laterites consist of kaolinite, diaspore, hematite, goethite, boehmite, anatase, siderite, rutile, and quartz. However, scanning electron microscopy (SEM) examinations of ore samples from the bluish gray (BGL) and the layered gray (LGL) units revealed that in addition to the mentioned mineral phases (Fig. 3a), there also exist crystalline particles of titanomagnetite (Figs. 3b, c, d), pyrite (within goethite) (Fig. 3e), and zircon (Fig. 3f) in this deposit.

\subsection{INDUSTRIAL APPLICATIONS}

The $\mathrm{Al}_{2} \mathrm{O}_{3} / \mathrm{SiO}_{2}$ ratio of lateritic-bauxitic ores (so called module) plays a crucial role in determining their industrial applications (Yalcin and Ilhan, 2013). The module values of Zan laterites have a range of 
Table 1 Results of chemical analyses (ICP-ES and ICP-MS) for major, minor, trace and rare earth elements along with Eu anomaly in the ores of the Zan lateritic deposit. The order of each number on samples is from the bottom to the top of the horizon.

\begin{tabular}{|c|c|c|c|c|c|c|c|c|c|c|}
\hline Sample & $\begin{array}{c}\text { GL } \\
(\mathrm{Z}-1)\end{array}$ & $\begin{array}{l}\text { BGL } \\
(\mathrm{Z}-2)\end{array}$ & $\begin{array}{l}\text { DGL } \\
\text { (Z-3) }\end{array}$ & $\begin{array}{l}\text { RGL } \\
(\mathrm{Z}-4)\end{array}$ & $\begin{array}{l}\text { GGL } \\
(\mathrm{Z}-5)\end{array}$ & $\begin{array}{l}\text { OGL } \\
(\mathrm{Z}-6)\end{array}$ & $\begin{array}{l}\text { LGL } \\
\text { (Z-7) }\end{array}$ & $\begin{array}{c}\text { YL } \\
(\mathrm{Z}-8)\end{array}$ & $\begin{array}{c}\text { RL } \\
\text { (Z-9) }\end{array}$ & $\begin{array}{c}\text { BL } \\
(\mathrm{Z}-10)\end{array}$ \\
\hline $\mathrm{SiO}_{2}(\mathrm{WT} \%)$ & 40.34 & 31.98 & 23.04 & 33.20 & 26.22 & 30.61 & 19.12 & 19.37 & 25.32 & 27.03 \\
\hline $\mathrm{Al}_{2} \mathrm{O}_{3}$ & 31.89 & 26.07 & 21.86 & 27.58 & 21.85 & 25.63 & 16.45 & 16.90 & 20.20 & 23.86 \\
\hline $\mathrm{Fe}_{2} \mathrm{O}_{3}$ & 5.09 & 16.20 & 12.49 & 16.43 & 24.59 & 20.32 & 35.19 & 43.77 & 35.78 & 24.07 \\
\hline MgO & 0.59 & 0.79 & 0.47 & 0.63 & 0.68 & 0.59 & 1.40 & 0.43 & 0.58 & 0.65 \\
\hline $\mathrm{CaO}$ & 0.46 & 0.40 & 11.68 & 0.32 & 0.35 & 0.35 & 0.65 & 0.25 & 0.34 & 0.86 \\
\hline $\mathrm{Na}_{2} \mathrm{O}$ & 0.15 & 0.12 & 0.12 & 0.11 & 0.09 & 0.12 & 0.18 & 0.08 & 0.14 & 0.08 \\
\hline $\mathbf{K}_{2} \mathbf{O}$ & 0.24 & 0.05 & 0.03 & 0.08 & 0.05 & 0.05 & 0.04 & 0.06 & 0.15 & 0.06 \\
\hline $\mathrm{TiO}_{2}$ & 3.01 & 4.79 & 4.86 & 4.21 & 3.51 & 4.76 & 3.31 & 3.35 & 3.00 & 3.55 \\
\hline $\mathbf{P}_{2} \mathbf{O}_{5}$ & 0.42 & 0.14 & 10.13 & 0.13 & 0.17 & 0.27 & 0.10 & 0.27 & 0.09 & 1.33 \\
\hline MnO & 0.02 & 0.11 & 0.09 & 0.07 & 0.55 & 0.05 & 0.04 & 0.08 & 0.06 & 0.10 \\
\hline $\mathrm{Cr}_{2} \mathrm{O}_{3}$ & 0.01 & 0.01 & 0.01 & 0.02 & 0.01 & 0.01 & 0.01 & 0.02 & 0.02 & 0.02 \\
\hline LOI & 17.60 & 19.10 & 14.60 & 17.00 & 21.70 & 16.90 & 23.30 & 15.20 & 14.10 & 17.70 \\
\hline Sum & 99.80 & 99.77 & 99.37 & 99.79 & 99.79 & 99.70 & 99.79 & 99.78 & 99.80 & 99.27 \\
\hline Ba (ppm) & 236.00 & 227.00 & 1139.00 & 157.00 & 183.00 & 221.00 & 165.00 & 162.00 & 163.00 & 504.00 \\
\hline $\mathbf{P b}$ & 1.90 & 2.30 & 3.00 & 2.30 & 1.00 & 10.40 & 1.50 & 1.90 & 1.50 & 3.30 \\
\hline $\mathrm{Ni}$ & 47.40 & 46.40 & 23.00 & 40.10 & 51.70 & 85.70 & 17.50 & 76.70 & 47.70 & 32.60 \\
\hline Co & 79.00 & 52.60 & 28.90 & 58.90 & 75.00 & 106.20 & 85.50 & 82.50 & 103.00 & 53.10 \\
\hline Ga & 40.90 & 25.10 & 34.30 & 26.20 & 19.30 & 53.80 & 18.80 & 29.20 & 15.80 & 21.80 \\
\hline Hf & 7.30 & 10.20 & 9.60 & 10.70 & 8.90 & 9.10 & 7.40 & 6.80 & 6.70 & 8.40 \\
\hline Nb & 46.60 & 70.20 & 65.70 & 71.80 & 58.20 & 68.80 & 48.50 & 51.80 & 47.10 & 59.20 \\
\hline $\mathbf{R b}$ & 10.60 & 2.40 & 1.00 & 3.00 & 1.80 & 2.50 & 1.30 & 8.90 & 4.40 & 2.20 \\
\hline $\mathrm{Sr}$ & 339.40 & 247.50 & 2160.80 & 172.80 & 333.00 & 575.00 & 158.20 & 210.70 & 222.30 & 4199.30 \\
\hline Ta & 2.60 & 4.60 & 4.20 & 4.50 & 3.40 & 4.20 & 3.40 & 3.30 & 3.00 & 3.80 \\
\hline Th & 4.90 & 6.30 & 5.50 & 8.00 & 6.30 & 6.10 & 4.90 & 4.90 & 5.10 & 6.50 \\
\hline $\mathbf{U}$ & 1.40 & 1.40 & 3.90 & 1.70 & 2.50 & 1.70 & 1.10 & 1.30 & 3.40 & 1.40 \\
\hline $\mathbf{V}$ & 183.00 & 266.00 & 189.00 & 179.00 & 249.00 & 241.00 & 203.00 & 207.00 & 277.00 & 202.00 \\
\hline $\mathbf{Z r}$ & 277.00 & 401.50 & 385.10 & 427.50 & 329.80 & 388.00 & 291.50 & 293.80 & 289.50 & 343.40 \\
\hline $\mathbf{Y}$ & 31.30 & 39.30 & 405.40 & 48.30 & 37.90 & 45.90 & 30.30 & 26.90 & 34.10 & 29.70 \\
\hline La (ppm) & 41.80 & 52.60 & 50.10 & 61.70 & 55.80 & 52.90 & 49.10 & 40.40 & 41.00 & 48.10 \\
\hline $\mathrm{Ce}$ & 90.80 & 106.80 & 133.50 & 123.70 & 113.20 & 113.20 & 94.30 & 82.70 & 78.80 & 104.50 \\
\hline Pr & 10.39 & 12.96 & 19.75 & 14.89 & 13.28 & 13.29 & 11.55 & 9.77 & 9.48 & 15.48 \\
\hline Nd & 41.90 & 56.30 & 132.20 & 55.40 & 53.00 & 51.90 & 42.30 & 38.30 & 39.20 & 89.20 \\
\hline Sm & 8.21 & 11.39 & 55.94 & 9.26 & 10.68 & 11.27 & 7.86 & 7.07 & 7.04 & 29.35 \\
\hline Eu & 2.49 & 3.73 & 23.30 & 3.03 & 3.39 & 4.06 & 2.74 & 2.33 & 2.29 & 9.53 \\
\hline Gd & 7.01 & 10.09 & 90.58 & 8.42 & 9.18 & 11.39 & 7.76 & 6.28 & 6.77 & 21.74 \\
\hline Tb & 1.09 & 1.53 & 11.51 & 1.55 & 1.44 & 1.83 & 1.17 & 1.02 & 1.09 & 2.22 \\
\hline Dy & 5.79 & 7.85 & 59.17 & 9.16 & 7.78 & 9.25 & 6.26 & 5.29 & 6.16 & 7.39 \\
\hline Ho & 1.14 & 1.54 & 11.39 & 1.92 & 1.45 & 1.70 & 1.18 & 1.02 & 1.27 & 1.07 \\
\hline $\mathbf{E r}$ & 3.25 & 3.99 & 28.22 & 5.39 & 3.67 & 4.79 & 3.00 & 2.73 & 3.45 & 2.61 \\
\hline Tm & 0.44 & 0.56 & 3.41 & 0.71 & 0.50 & 0.66 & 0.46 & 0.37 & 0.45 & 0.43 \\
\hline $\mathbf{Y b}$ & 2.82 & 3.57 & 19.58 & 4.83 & 3.30 & 3.82 & 2.57 & 2.22 & 3.08 & 2.94 \\
\hline Lu & 0.45 & 0.49 & 2.74 & 0.68 & 0.46 & 0.57 & 0.37 & 0.34 & 0.39 & 0.42 \\
\hline $\mathbf{E u} / \mathbf{E u} \mathbf{u}^{*}$ & 1.15 & 1.01 & 1.07 & 1.07 & 1.10 & 1.05 & 1.05 & 1.00 & 1.06 & 1.00 \\
\hline
\end{tabular}

0.79 to 0.94 . Based on the classification of Voros (1979), the ores at the Zan in light of aluminum extraction are considered as low quality. However, comparison of the mean values of major constituent oxides of the studied ores with the ideal chemical composition of the lateritic-bauxitic ores for industrial applications (Edwards and Atkinson, 1986; Manning, 1995) shows that the Fe-poor and Fe-rich parts of the horizon at Zan have great potential for uses (as raw materials) in refractory and cement industries, respectively. 

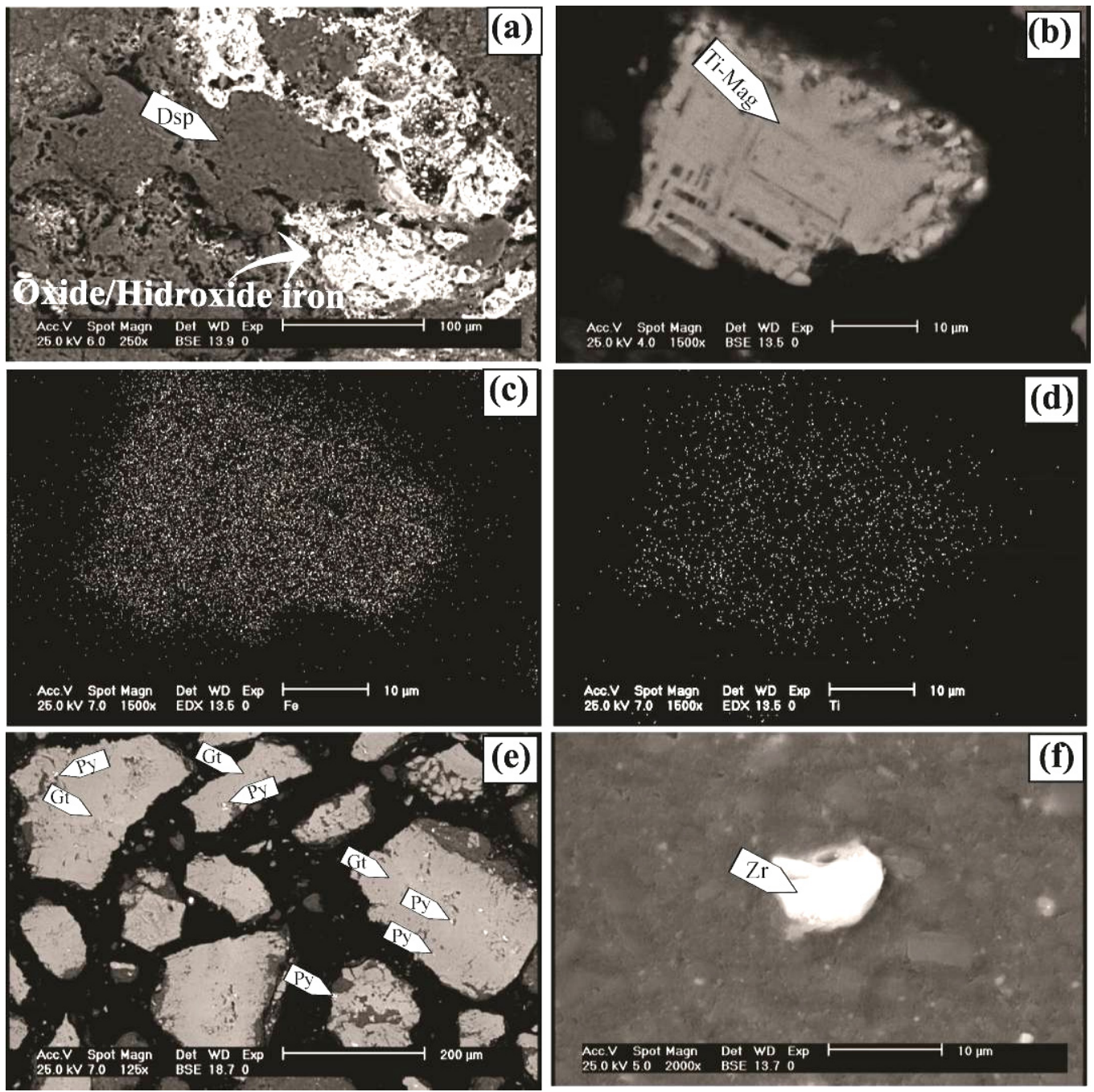

Fig. 3 Scanning electron microscopic microphotographs of The Zan lateritic ores. (a) Tabular fragment of diaspore along with Fe-oxide and - hydroxide in the ore of GL unit. (b) The presence of titanomagnetite crystal in LGL unit. (c) Concentration of iron in titanomagnetite. (d) Concentration of titanium in titanomagnetite. (e) Very fine-grained pyrites within goethite in BGL unit. (f) A solitary crystal of zircon in unit BGL. Abbreviations: $\mathrm{Zr}=$ zircon, $\mathrm{Dsp}=$ Diaspore, $\mathrm{Ti}-\mathrm{Mag}=$ titanomagnetite, $\mathrm{Gt}=$ goethite, and Py $=$ pyrite

\subsection{MASS CHANGE CALCULATIONS}

Customarily, calculations of mass change for elements during weathering are carried out by employing two methods, (1) iso-volume (Brimhall and Dietrich, 1987; Brimhall et al., 1991) and (2) immobile element (Nesbitt, 1979; MacLean and Kranidiotis, 1987; MacLean, 1990; MacLean and Barrett, 1993). In this study, for determination of degree of mobility and enrichment of elements during lateritization processes, absolute weathering index (AWI) of immobile element (Nesbitt, 1979) was used. The calculations were done with an assumption of $\mathrm{Th}$ as immobile element (Wimpenny et al., 2007) and of taking the mean composition of upper continental crust (UCC) (Taylor and McLennan, 1985) as parent rock for the Zan deposit by using the following equation:

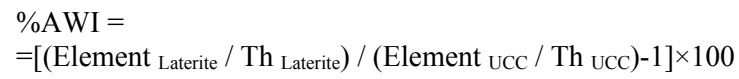

This investigation was carried out for five groups, (1) major and minor elements, (2) large ion lithophile elements (LILE), (3) transition trace elements (TTE), (4) high field strength elements (HFSE), and (5) rare earth elements (REEs).

Major and minor elements (Al, Fe, Ti, Si, Na, K, Ca, Mg, Mn, and P): The mass change calculations show that silica relative to alkali and alkali earth elements suffered moderate leaching (Figs. 4a, b). This is likely owing to formation of secondary clay minerals like kaolinite during lateritization. Enrichment of Al and Ti in the profile (Fig. 4a) could be due to the coupled alteration of silicates minerals (feldspars and ferromagnesians) and formation of $\mathrm{Al}$ 


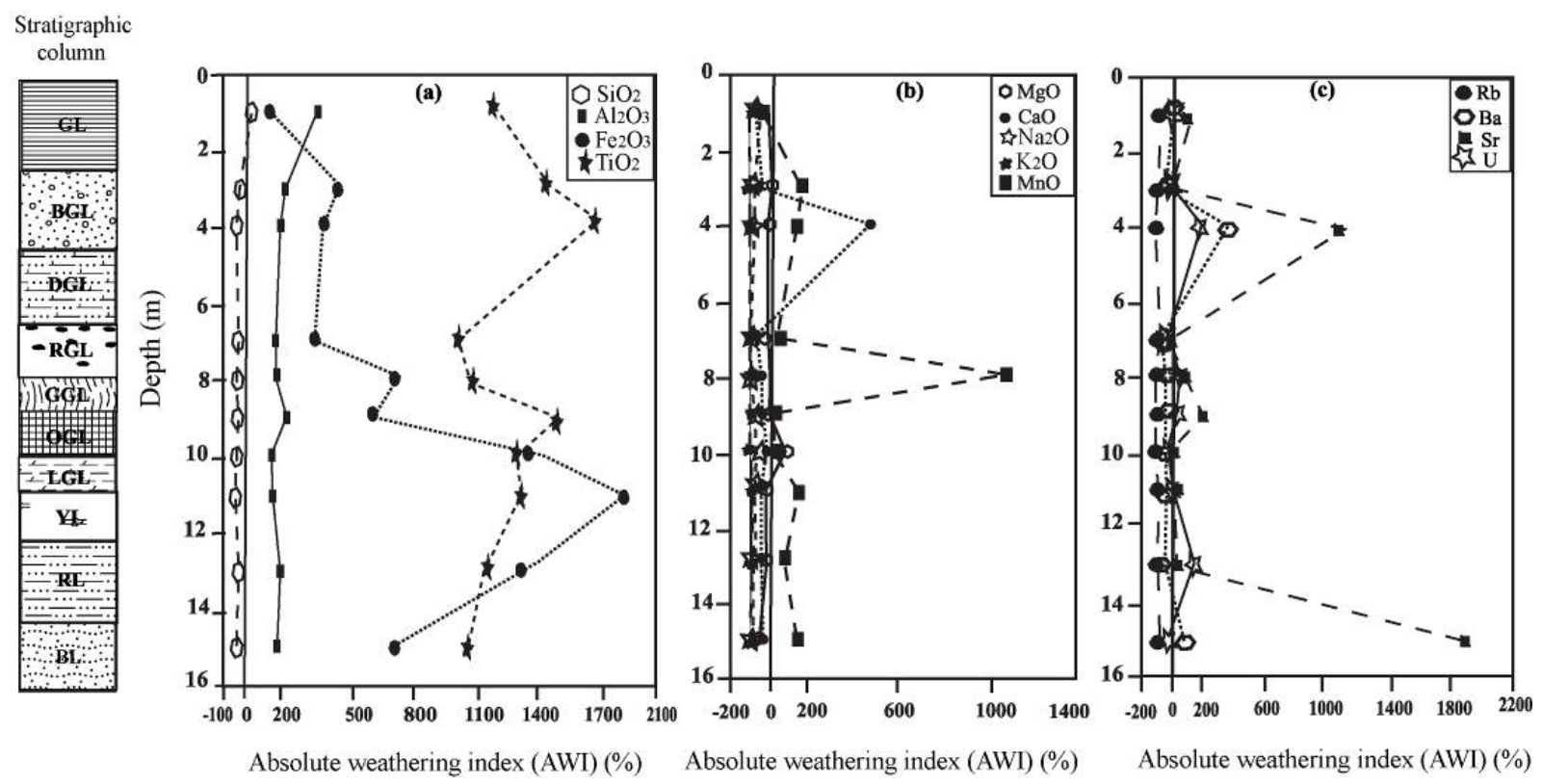

Fig. 4 Patterns of mass changes for major and minor oxides (a, b) and large ion lithophile elements (c) in various units of the Zan studied profile.

and Ti-bearing minerals. Non-rhythmic distribution of Fe in the profile and its increase toward bedrocks may be explicative of fluctuation of underground water table level. It seems that decomposition of organic matters in the upper parts of the profile provided locally acidic and reducing conditions which resulted in movement of iron downwardly and its subsequent fixation in the lower parts of the profile. The mass change calculations reveal that lateritization processes at Zan were accompanied by moderate to strong leaching of $\mathrm{Ca}, \mathrm{Na}, \mathrm{K}$, and $\mathrm{Mg}$ and to a lesser extent by $\mathrm{Mn}$ (Fig. 4b). It seems that $\mathrm{Na}, \mathrm{Ca}$, and $\mathrm{K}$ were released into weathering solutions. On the other hand, depletion of $\mathrm{Mg}$ and $\mathrm{Mn}$ from the system is related to decomposition of ferromagnesian minerals. Erichment of $\mathrm{Mn}$, however, in the GL-unit exhibits that $\mathrm{Mn}^{2+}$ was oxidized to $\mathrm{Mn}^{4+}$ and was fixed as insoluble oxides and hydroxides (Koppi et al., 1996). Enrichment of $\mathrm{CaO}$ in the DGL-unit is due to deposition of $\mathrm{CaCO}_{3}$ by supergene solutions in this part of the profile.

Large ion lithophile elements ( $\mathrm{Rb}, \mathrm{Ba}, \mathrm{Sr}$, and $\mathrm{U})$ : Depletion or enrichment of trace elements in the lateritic profiles depends on their host minerals in the parent rocks. Mobile trace elements, if their host minerals are insoluble, can become enriched in laterites (Meshram and Randive, 2011). Rb was released during feldspar weathering (break-down) causing its depletion in all of the lateritic units (Fig. 4c). The mass changes of $\mathrm{Ba}, \mathrm{Sr}$ and $\mathrm{U}$ show their enrichment in some units (Fig. 4c). The positive correlation between pairs of U-Y $(r=0.85)$ and $\mathrm{U}-\mathrm{P}_{2} \mathrm{O}_{5}(\mathrm{r}=0.71)$ could be due to the presence of $U$ in the crystal structure of $Y$-rich minerals like xenotime $\left(\mathrm{YPO}_{4}\right)($ Gonzales-Lopez et al., 2005) that was not identified by XRD analysis as the result of its low concentration. The positive correlation between pairs of $\mathrm{Sr}-\mathrm{P}_{2} \mathrm{O}_{5}(\mathrm{r}=0.82)$ and $\mathrm{Sr}-\mathrm{Ca}(\mathrm{r}=0.73)$ may be suggestive of likely hosting of crandallite mineral group for Sr. These minerals are commonly formed by alteration of apatite in karst bauxites (Bardossy, 1982). The moderate to strong positive correlation between $\mathrm{Ba}$ and $\mathrm{P}_{2} \mathrm{O}_{5}(\mathrm{r}=0.83)$ and between $\mathrm{Ba}$ and REEs $(r>0.7)$ may provide reason for the presence of the Al-bearing secondary phosphates like gorceixite $\left[\mathrm{BaAl}_{3}\left(\mathrm{LREE}_{2} \mathrm{PO}_{4}\right)_{2}(\mathrm{OH})_{5} \cdot \mathrm{H}_{2} \mathrm{O}\right]$ (Costa and Araujo, 1996) that was not detected by XRD analysis.

Transition trace elements ( $\mathrm{Ni}, \mathrm{Co}, \mathrm{Cr}$, and V): The variation of $\mathrm{AWI}$ values for $\mathrm{Co}, \mathrm{Cr}, \mathrm{Ni}$, and $\mathrm{V}$ at Zan was irregular but incremental (Fig. 5a). Iron colloids have effective role in transportation and concentration of a group of trace elements, especially transitional trace elements, during weathering processes (Pokrovsky et al., 2006). Considering the moderate and positive correlation between pairs of Fe-Co $(r=0.75), \quad \mathrm{Fe}-\mathrm{V}(\mathrm{r}=0.69)$, and $\mathrm{Fe}-\mathrm{Cr}$ $(r=0.72)$, the role of Fe-oxides and -hydroxides in fixation and concentration of these elements (as the result of scavenging and adsorption) can be established. Among the transition trace elements, Ni has very weak correlation with $\mathrm{Fe}$ but moderate and positive correlation with $\mathrm{SiO}_{2}(\mathrm{r}=0.68)$. This may be indicative of being clay minerals as potential fixing agent for $\mathrm{Ni}$ in the studied profile.

High field strength elements ( $\mathrm{Y}, \mathrm{Nb}, \mathrm{Zr}$, and $\mathrm{Hf})$ : These elements were enriched in all of the lateritic units (Fig. 5b). It seems that the enrichment of these almost immobile elements took place in an authigenic 


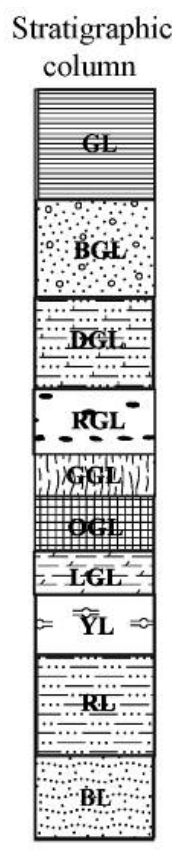

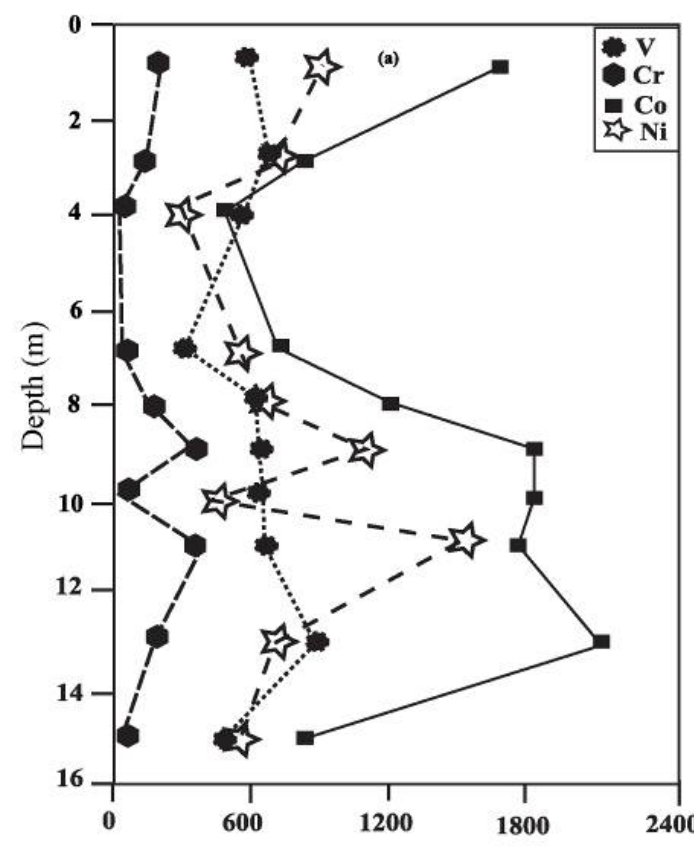

Absolute weathering index (AWI) (\%)

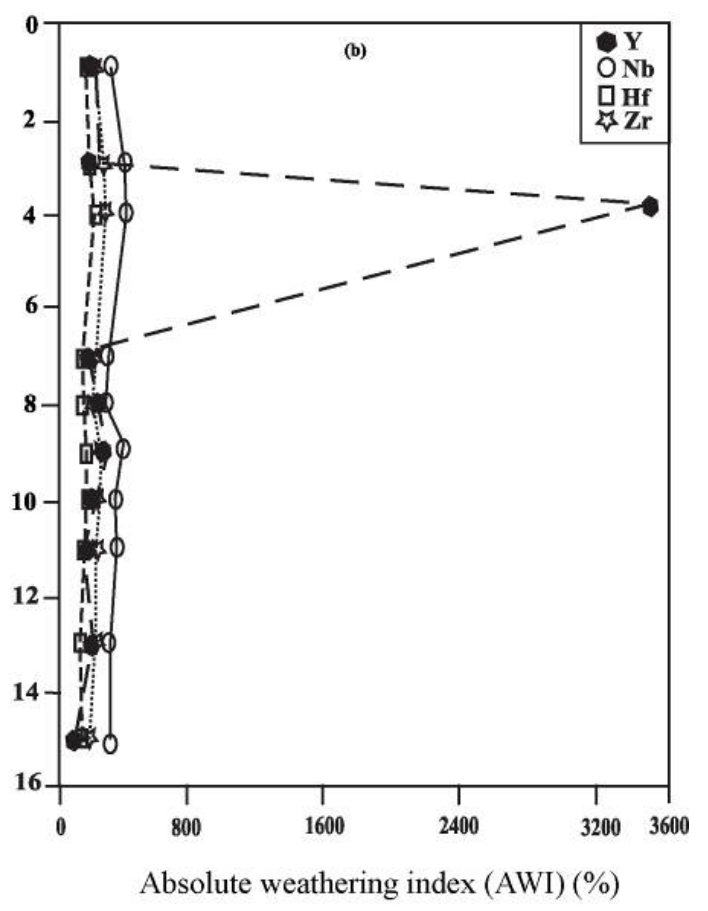

Absolute weathering index (AWI) (\%)

Fig. 5 Patterns of mass changes for (a) transition trace elements and (b) high field strength elements in various units of the Zan studied profile.
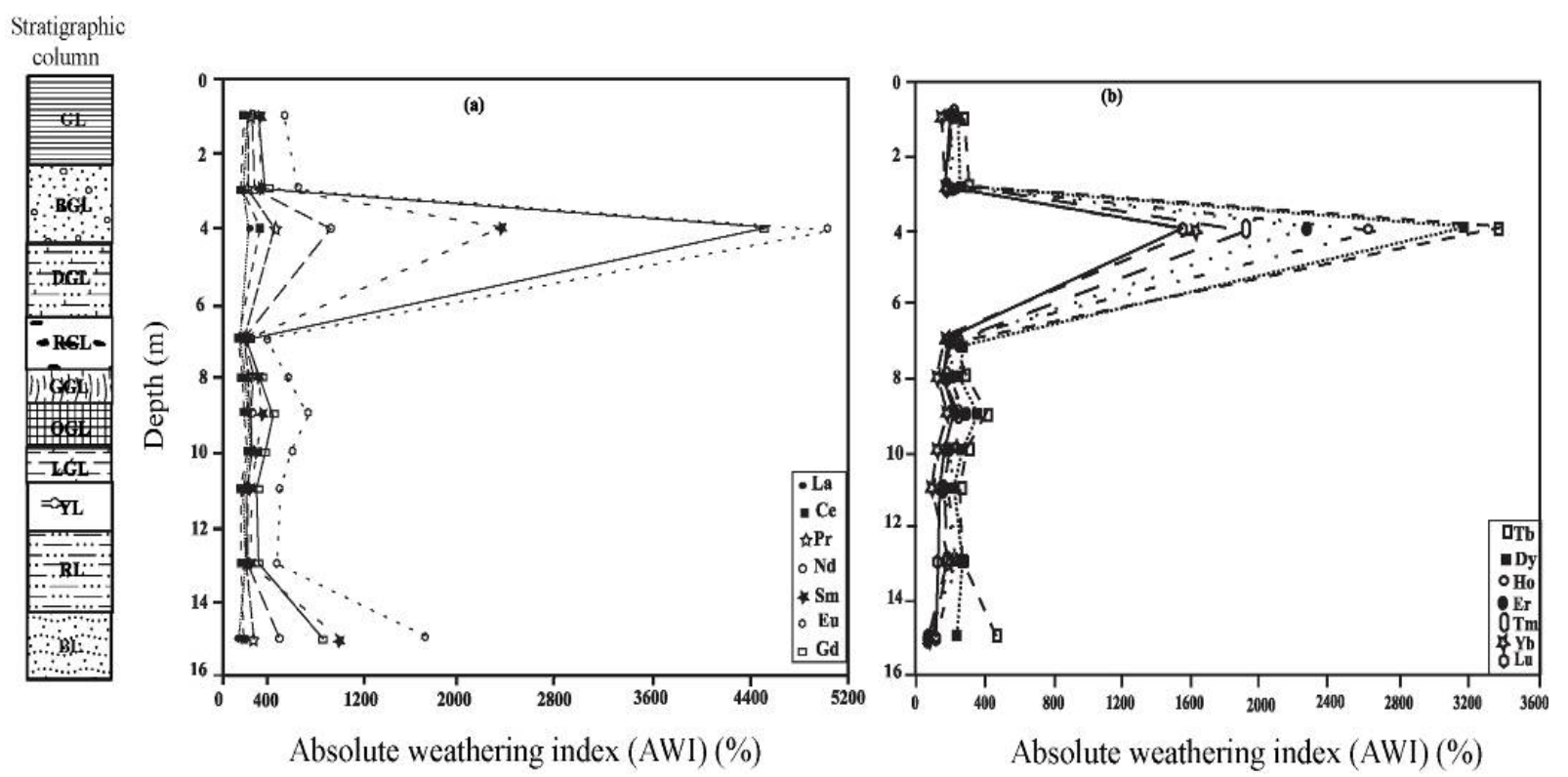

Fig. 6 Patterns of mass changes for (a) light rare earth elements (LREEs) and (b) heavy rare earth elements (HREEs) in various units of the Zan studied profile.

state. The moderate and positive correlation between $\mathrm{Y}$ and $\mathrm{Al}(\mathrm{r}=0.69)$ is probably owing to the presence of this element within the crystal structure of the Al-bearing mineral phases. The positive correlation between pairs of Ti-Hf $(\mathrm{r}=0.76)$, Ti-Nb $(\mathrm{r}=0.77)$, $\mathrm{Zr}-\mathrm{Hf}(\mathrm{r}=0.83)$, and $\mathrm{Zr}-\mathrm{Nb}(\mathrm{r}=0.81)$ may reflect that $\mathrm{Nb}$ and $\mathrm{Hf}$ are hosted chiefly by Ti-oxides and to a lesser extent by zircon in the profile.
Rare earth elements: The pattern of mass changes of LREEs and HREEs in the Zan lateritic deposit shows an incremental trend (Figs. 6a, b). The remarkable mass increase of REEs in the DGL unit is likely in connection with $\mathrm{pH}$ increase and formation of REE-bearing carbonate minerals. The good and positive correlation between lanthanides and $\mathrm{Zr}$ $(\mathrm{r}>0.74)$ and between lanthanides and $\mathrm{Ti}(\mathrm{r}>0.72)$ 

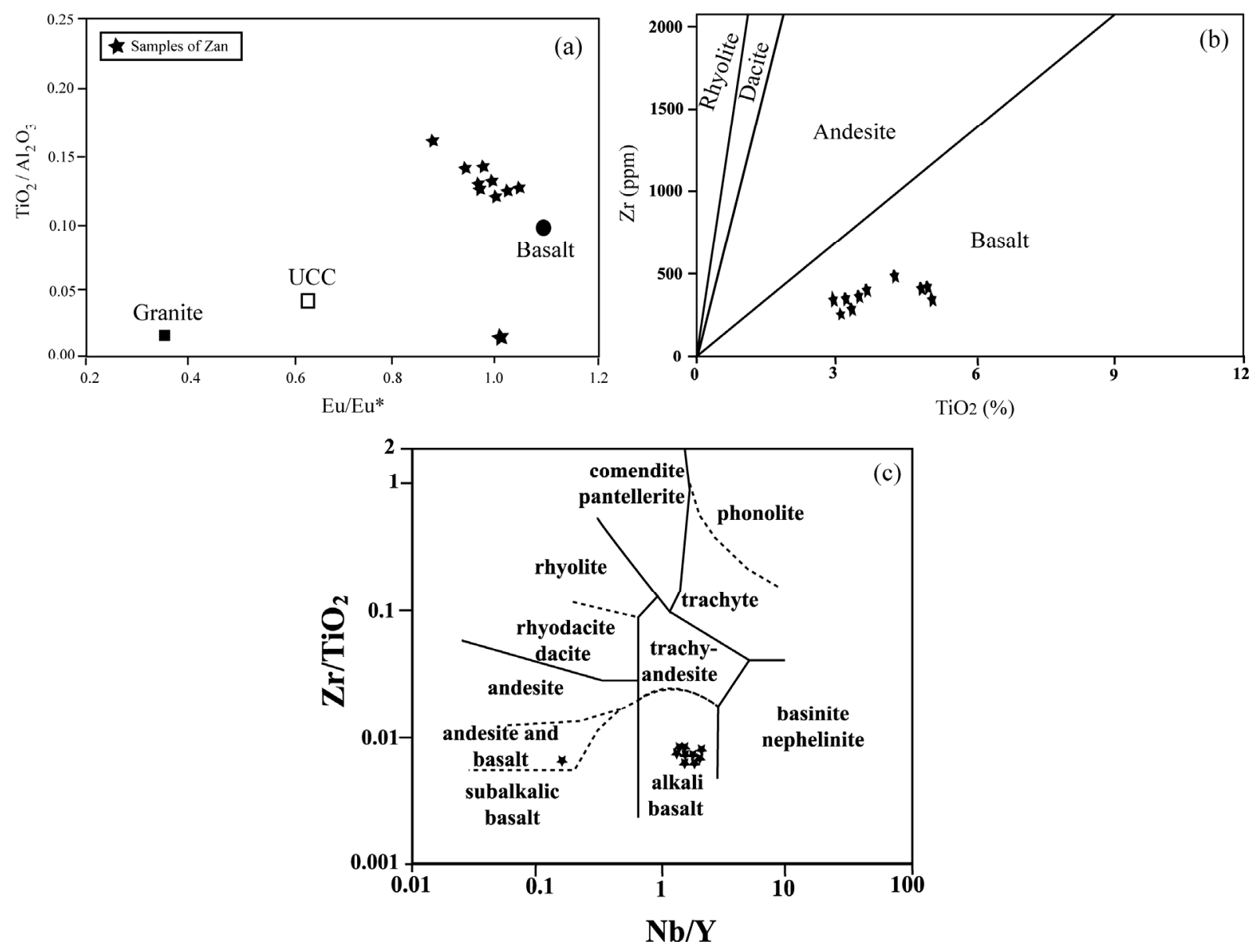

Fig. 7 A bivariate plot of Eu anomaly versus $\mathrm{TiO}_{2} / \mathrm{Al}_{2} \mathrm{O}_{3}$ (MacLean et al., 1997) for mean composition of upper continental Crust (UCC), granite, basalt, and the Zan lateritic samples. (b) A bivariate plot of $\mathrm{TiO}_{2}$ versus $\mathrm{Zr}$ (Hallberg, 1984) on which the Zan data (filled asterisk) lie in basaltic parent rock domain. (c) A bivariate plot of $\mathrm{Nb} / \mathrm{Y}$ versus $\mathrm{Zr} / \mathrm{TiO}_{2}$ (Floyd and Winchester, 1978) on which the alkali basalt is shown to be the potential precursor for the Zan lateritic ores.

reveals that titanium oxides and zircon are the major hosts for REEs. LREEs have weak but positive correlation with $\mathrm{Mn}(\mathrm{r}>0.35)$, Al $(0.25<\mathrm{r}<0.4)$, and $\mathrm{Si}(0.1<\mathrm{r}<0.4)$ indicating the weak role of Mn-oxides and clay minerals in hosting LREEs.

\subsection{PARENT ROCK COMPOSITION}

Commonly lateritic-bauxitic deposits have compositions and textures that are related to underlying host rocks (Bardossy and Aleva, 1990). However, this can hardly be observed for bauxites developed on limestone. A wide range of parent rocks for karst bauxites have been proposed including argillaceous materials (MacLean et al., 1997), mafic igneous rocks (Calagari and Abedini, 2007; Esmaeily et al., 2010); volcanic ashes (MacLean et al., 1997), and wind-drifted materials (Brimhall et al., 1988; Pyk, 1988).

$\mathrm{Eu}$ anomaly remains commonly constant during weathering processes (Mongelli, 1993; Mameli et al., 2007; Abedini and Calagari, 2013a). Al and Ti also remain immobile during lateritization (MacLean et al.,
1997; Mameli et al., 2007) and have a great potential to get into sediments. Therefore, $\mathrm{TiO}_{2} / \mathrm{Al}_{2} \mathrm{O}_{3}$ and $\mathrm{Eu}$ anomaly are sensitive index for determination of parent rocks. The mean composition values of upper continental crust (UCC), basalt, granite (Taylor and McLennan, 1985), and various units of the Zan lateritic ores are illustrated on $\mathrm{Eu}$ anomaly versus $\mathrm{TiO}_{2} / \mathrm{Al}_{2} \mathrm{O}_{3}$ plot (Fig. 7a). According to Figure $7 \mathrm{a}$, the Zan data plots in the basalt (as precursor) domain. Further investigations revealed that the $\mathrm{Zr} / \mathrm{TiO}_{2}$ in lateritic deposits is commonly similar to that of parent rocks and can provide favorable geochemical information for determination of parent rocks (Hallberg, 1984). On the basis of this premise, the position of the $\mathrm{Zan}$ data on $\mathrm{TiO}_{2}$ versus $\mathrm{Zr}$ bivariate plot also suggests a basaltic composition for the parent rocks (Fig. 7b). Floyd and Winchester (1978) used the bivariate plot of $\mathrm{Nb} / \mathrm{Y}$ versus $\mathrm{Zr} / \mathrm{TiO}_{2}$ for determination of parent rocks of lateritic deposits (this method, especially when the parent rocks are extrusive igneous rocks, is very applicable). $\mathrm{The} \mathrm{Zr} / \mathrm{Ti}$ of the parent rock remains constant during 
lateritization processes (Hill et al., 2000). The Zan data on $\mathrm{Nb} / \mathrm{Y}$ versus $\mathrm{Zr} / \mathrm{TiO}_{2}$ plot reflects the alkali basalt composition for the precursor of the horizon (Fig. 7c).

Interpretation of a basic source material for Zan laterite deposit is supported by palaeogeography evidence of Iran. In the Cental Alborz structural zone, the early Jurassic andesite to basalt volcanic rocks cover an eroded and often karstified surface, at the base of the Shemshak Formation (Annelles et al., 1975; Nabavi and Seyed-Emami, 1977; Nabavi, 1987; Esmaeily et al., 2010). The volcanic activity occasionally continued into the lower part of the Shemshak Formation.

\section{CONCLUSIONS}

Calculations of the degree of absolute weathering index (AWI) demonstrate that lateritization of the Zan horizon was resulted by desilicification and removal of alkali and alkalineearth elements coupled with $\mathrm{Al}$ and $\mathrm{Fe}$ enrichment. Despite remaining in the residual system, Fe shows strong variation within the horizon. Based upon correlation coefficients among various elements, it can be deduced that the distribution of trace and rare earth elements in various unit within this deposit was controlled essentially by neomorph accessory and resistant mineral phases. In general, distribution of REEs, $\mathrm{Hf}$, and $\mathrm{Nb}$ in the lateritic ores was controlled substantially by minerals like Ti-oxides and zircon. Fe-oxides and -hydroxides host elements such as Co, $\mathrm{V}$, and Cr. Clay minerals are the chief controlling agents for $\mathrm{Ni}$ distribution in this deposit. Distribution of $\mathrm{Y}$ was mainly controlled by Al-bearing mineral phases. The phosphate minerals played crucial roles for concentration of $\mathrm{Ba}, \mathrm{U}$, and $\mathrm{Sr}$ during lateritization processes. Palaeogeography evidence as well as geochemical indices such as $\mathrm{TiO}_{2} / \mathrm{Al}_{2} \mathrm{O}_{3}$ and values of $\mathrm{Eu}$ anomaly reveals that the Zan lateritic horizon is a weathering product of basalt.

\section{ACKNOWLEGEMENTS}

This work was enjoyed financial support by the Research Deputy Bureau of the University of Tabriz. The authors would like to express their thanks and appreciations to the authorities of this bureau. Special thanks are also expressed to Prof. Josef Stemberk for his editorial assistance and to two anonymous reviewers for making critical comments on this manuscript.

\section{REFERENCES}

Abedini, A. and Calagari, A.A.: 2014, REE geochemical characteristics of titanium-rich bauxites: the Permian Kanigorgeh horizon, NW Iran. Turkish Journal of Earth Sciences, 23, No. 5, 513-532. DOI: $10.3906 /$ yer-1404-11

Abedini, A., Calagari, A.A. and Mikaeili, K.: 2014, Geochemical characteristics of laterites: the Alibaltalu deposit, Iran. Bulletin of the Mineral Research and Exploration, 148, 69-84.
Abedini, A. and Calagari, A.A.: 2013a, Rare earth elements geochemistry of Sheikh-Marut laterite deposit, NW Mahabd, West-Azarbaidjan province, Iran. Acta Geologica Sinica-English Edition, 87, No. 1, 176185. DOI: $10.1111 / 1755-6724.12039$

Abedini, A. and Calagari, A.A.: 2013b, Geochemical characteristics of Kanigorgeh ferruginous bauxite horizon, West-Azarbaidjan province, NW Iran. Periodico di Mineralogia, 82, No. 1, 1-23. DOI: 10.2451/2013PM0001

Abedini, A. and Calagari, A.A.: 2013c, Geochemical characteristics of bauxites: the Permian Shahindezh horizon, NW Iran. Neues Jahrbuch für Geologie und Paläontologie-Abhandlungen, 270, No. 3, 301-324. DOI: $10.1127 / 0077-7749 / 2013 / 0371$

Aghanabati, A.: 2004, Geology of Iran (Persian version), Geological Survey of Iran.

Amini, B and Khalatbari, M.: 1972, Geologic map of Damavand quadrangle (1: 100000). Geological Survey of Iran.

Annelles, R.N., Arthurton, R.S., Bazely, R.A. and Davies, R.G.: 1975, E3-E4 Quadrangle, 1:100000 scale geological map and explanatory text of Qazvin and Rasht. Geological Survey of Iran, Tehran.

Bardossy, G. and Aleva, G.J.J.: 1990, Lateritic Bauxites. Developments in Economic Geology, 27, 1-552.

Bardossy, G.: 1982, Karst Bauxites (bauxite deposits on carbonate rocks). Developments in Economic Geology, 14, 1-441.

Berger, A., Janots, E., Gnos, E., Frei, R. and Bernier, F.: 2014, Rare earth element mineralogy and geochemistry in a laterite profile from Madagascar. Applied Geochemistry, 41, 218-228.

DOI: 10.1016/j.apgeochem.2013.12.013

Bogatyrev, B.A., Zhukov, V.V. and Tsekhovsky, Y.G.: 2009, Formation conditions and regularities of the distribution of large and superlarge bauxite deposits. Lithology and Mineral Research, 44, No. 2, 135-151. DOI: $10.1134 / \mathrm{S} 0024490209020035$

Brimhall, G.H., Lewis, C.J., Ague, I.J., Dietrich, W.E. and Hample Rix, P.: 1988, Metal enrichment in bauxites by deposition of chemically mature aeolian dust. Nature, 333, 819-824. DOI: 10.1038/333819a0

Brimhall, G.H. and Ditrich, W.E.: 1987, Constitutive mass balance Differential feldspar weathering in granites relations between chemical composition, volume, density, porosity, and strain in metasomatic hydrochemical systems: results on weathering and pedogenesis. Geochimica et Cosmochimica Acta, 51, No. 3, 567-587. DOI: 10.1016/0016-7037(87)90070-6

Brimhall, G.H., Lewis, C.J., Ford, C., Bratt, J., Taylor, G. and Warin, O.: 1991, Quantitative geochemical approach to pedogenesis: importance of parent material reduction, volumetric expansion and eolian influx in laterization. Geoderma, 51, No. 1-4, 51-91. DOI: 10.1016/0016-7061(91)90066-3

Calagari, A.A. and Abedini, A.: 2007, Geochemical investigations on Permo-Triassic bauxite horizon at Kanisheeteh, east of Bukan, West-Azarbaidjan, Iran. Journal of Geochemical Exploration, 94, No. 1-3, 118. DOI: 10.1016/j.gexplo.2007.04.003

Calagari, A.A., Kangrani, F. and Abedini, A.: 2010, Geochemistry of major, trace and rare earth elements in Biglar Permo-Triassic bauxite deposit, Northwest of Abgarm, Ghazvin Province, Iran. Journal of Sciences, Islamic Republic of Iran, 21, No. 3, 225-236. 
Costa, M.L. and Araujo, E.S.: 1996, Application of multielement geochemistry in Au-phosphate-bearing lateritic crusts for identification of their parent rocks. Journal of Geochemical Exploration, 57, No. 1-3, 257-272. DOI: 10.1016/S0375-6742(96)00041-6

Edwards, R. and Atkinson, K.: 1986, Ore Deposit Geology. London, Chapman and Hall, 1-496.

Esmaeily, D., Rahimpour-Bonab, H., Esna-Ashari, A. and Kananian, A.: 2010, Petrography and geochemistry of the Jajarm karst bauxite ore deposit, NE Iran: implications for source rock material and ore genesis. Turkish Journal of Earth Sciences, 19, 267-284. DOI: 10.3906/yer-0806-15

Floyd, P.A. and Winchester, J.A.: 1978, Identification and discrimination of altered and metamorphosed volcanic rocks using immobile chemical elements. Chemical Geology, 21, No. 3-4, 291-306. DOI: 10.1016/0009-2541(78)90050-5

Giorgis, I., Bonetto, S., Giustetto, R., Lawane, A., Pantet, A., Rossetti, P., Thomassin, J. and Vinai, R.: 2014, The lateritic profile of Balkouin, Burkina Faso: geochemistry, mineralogy and genesis. Journal of African Earth Sciences, 90, 31-48. DOI: $10.1016 /$ j.jafrearsci.2013.11.006

Gonzales-Lopez, J.M.G., Bauluz, B., Fernandez-Nieto, C. and Oliete, A.Y.: 2005, Factors controlling the trace element distribution in fine-grained rocks: the Albian kaolinite-rich deposits of the Oliete Basin (NE Spain). Chemical Geology, 214, No. 1-2, 1-19. DOI: 10.1016/j.chemgeo.2004.08.024

Gu, J., Huang, Z., Fan, H., Jin, Z., Yan, Z. and Zhang, J.: 2013, Mineralogy, geochemistry, and genesis of lateritic bauxite deposits in the Wuchuan-Zheng'anDaozhen area, Northern Guizhou Province, China. Journal of Geochemical Exploration, 130, 44-59. DOI: 10.1016/j.gexplo.2013.03.003

Hallberg, J.A.: 1984, A geochemical aid to igneous rocks type identification in deeply weathered terrain. Journal of Geochemical Exploration, 20, No. 1, 1-8. DOI: $10.1016 / 0375-6742(84) 90085-2$

Hanili, N.: 2013, Geological and geochemical evolution of the Bolkardaği bauxite deposits, Karaman, Turkey: transformation from shale to bauxite. Journal of Geochemical Exploration, 113, 118-137. DOI: $10.1016 /$ j.gexplo.2013.04.004

Hill, I.G., Worden, R.H.G. and Meighan, I.G.: 2000, Geochemical evolution of paleolaterite: the interbasaltic Formation, Northern Ireland. Chemical Geology, 166, No. 1-2, 65-84.

DOI: 10.1016/S0009-2541(99)00179-5

Karadağ, M., Kupeli, S., Arik, F., Ayhan, A., Zedef, V. and Doyen, A.: 2009, Rare earth element (REE) geochemistry and genetic implications of the Mortas bauxite deposit Seydisehir/Konya-southern Turkey. Chemie der Erde-Geochemstry, 69, No. 2, 143-159. DOI: $10.1016 /$ j.chemer.2008.04.005

Koppi, A.J., Edis, R., Foeld, D.J., Geering, H.R., Klessa, D.A. and Cockayne, D.J.H.: 1996, REEs trends and $\mathrm{Ce}-\mathrm{U}-\mathrm{Mn}$ associations in weathered rock from Koongarra, northern territory, Australia. Geochimica et Cosmochimica Acta, 60, No. 10, 1695-1707. DOI: 10.1016/0016-7037(96)00047-6

Kurtz, A.C., Derry, L.A., Chadwick, O.A. and Alfano, M.: 2000, Refractory element mobility in volcanic soils. Geology, 28, No. 8, 683-686. DOI: $10.1130 / 0091-7613$
Li, Z., Din, J., Xu, J., Liao, C., Yin, F., Lü, T., Cheng, C. and Li, J.: 2013, Discovery of the REE minerals in the Wulong-Nanchuan bauxite deposits, Chongqing, China: insights on conditions of formation and processes. Journal of Geochemical Exploration, 133, 88-102. DOI: 10.1016/j.gexplo.2013.06.016

Liu, X., Wang, Q., Deng, J., Zhang, Q., Sun, S. and Meng, J.: 2010, Mineralogical and geochemical investigations of the Dajia Salento-type bauxite deposits, western Guangxi, China. Journal of Geochemical Exploration, 105, No. 3, 137-152. DOI: $10.1016 /$ j.gexplo.2010.04.012

MacLean, W.H.: 1990, Mass change calculations in altered rock series. Mineralium Deposita, 25, 44-49.

MacLean, W.H., Bonavia, F.F. and Sanna, G.: 1997, Argillite debris converted to bauxite during karst weathering: Evidence from immobile element geochemistry at the Olmedo Deposit, Sardinia. Mineralium Deposita, 32, No. 6, 607-616. DOI: $10.1007 / \mathrm{s} 001260050126$

MacLean, W.H. and Kranidiotis, P.: 1987, Immobile elements as monitors of mass transfer in hydrothermal alteration: phelps Dodge massive sulfide deposit. Matagami, Quebec. Economic Geology, 82, No. 4, 951-962. DOI: 10.2113/gsecongeo.82.4.951

MacLean, W.H. and Barrett, T.J.: 1993, Lithogeochemical techniques using immobile elements. Journal of Geochemical Exploration, 48, No. 2, 109-133. DOI: 10.1016/0375-6742(93)90002-4

Mameli, P., Mongelli, G., Oggiano, G. and Dinelli, E.: 2007, Geological, geochemical and mineralogical features of some bauxite deposits from Nurra (Western Sardinia, Itly): insights on conditions of formation and parental affinity. International Journal of Earth Sciences, 96, No. 5, 887-902. DOI: 10.1007/s00531.006.0142.2

Manning, D.A.C.: 1995, Introduction to industrial minerals. London (Chapman and Hall), 1-276.

Meshram, R.R. and Randive, K.R.: 2011, Geochemical study of laterites of the Jamnagar district, Gujarat, India: Implications on parent rock, mineralogy and tectonics. Journal of Asian Earth Sciences, 42, No. 6, 1271-1287. DOI: 10.1016/j.jseaes.2011.07.014

Mongelli, G.: 1993, REE and other trace elements in a granitic weathering profile from "Serre", Southern Italy. Chemical Geology, 103, No. 1-4, 17-25. DOI: 10.1016/0009-2541(93)90288-T

Nabavi, M.H. and Seyed-Emami, K.: 1977, Sinemudan ammonites from the Shemshak Formation of North Iran (Semnan area, Alborz). Neues Jahrbuch für Geologie und Paläontologie-Abhandlungen, 153, 7085.

Nabavi, M.H.: 1987, Geological map of Semnan sheet, 1:100000 scale. Geological Survey of Iran, Tehran.

Nabavi, M.: 1976, An introduction to the geology of Iran (in Persian). Geological Survey of Iran Publication, 1109.

Nesbitt, H.W.: 1979, Mobility and fractionation of rare elements during weathering of a granodiorite. Nature, 279, 206-210. DOI: 10.1038/279206a0

Nyakairu, G.W.A., Koeberl, C. and Kurzweil, H.: 2001, The Buwambo kaolin deposit in Central Uganda: mineralogical and chemical composition. Geochemical Journal, 35, No. 4, 245-256. DOI: $10.2343 /$ geochemj.35.245

Pokrovsky, O.S., Schott, J. and Dupre, B.: 2006, Trace element fractionation and transport in boreal rivers 
and soil porewaters of permafrost-domonated basaltic terrain in Central Siberia. Geochimica et Cosmochimica Acta, 70, No. 13, 3239-3260.

DOI: $10.1016 /$ j.gca.2006.04.008

Pyk, K.: 1988, Bauxites gathering dust. Nature, 333, 800801. DOI: $10.1038 / 333800 \mathrm{a} 0$

Taylor, S.R. and McLennan, S.M.: 1985, The continental crust: its composition and evolution, Blackwell; Oxford, 1-312.

Voros, I.: 1979, Definition of bauxites; principles and methods of bauxite prospecting. Aluteru-Fki's, Printing Slop.

Wimpenny, J., Gannoun, A., Burton, K.W., Widdowson, M., Jamed, R.H. and Gilason, S.R.: 2007, Rhenium and osmium isotope and elemental behaviour accompanying laterite formation in the Deccan region of India. Earth and Planetary Science Letters, 261, No. 1-2, 239-258. DOI: 10.1016/j.epsl.2007.06.028

Yalcin, M.G and Ilhan, S.: 2013, Major and trace element geochemistry of bauxites: Ayranci, Karaman, Central Bolkardag, Turkey. Asian Journal of Chemistry, 25, No. 5, 2893-2904.

DOI: org/10.14233/ajchem.2013.14275

Yalcin, M.G. and Ilhan, S.: 2008, Major and trace element geochemistry of terra rossa soil in the Kucukkoras region, Karaman, Turkey. Geochemistry International (Geokhimiya), 46, No. 10, 1038-1054.

DOI: $10.1134 / \mathrm{S} 00167029810008 \mathrm{X}$

Zarasvandi, A., Carranza, E.J.M. and Ellahi, S.S.: 2012, Geological, geochemical, and mineralogical characteristics of the Mandan and Deh-now bauxite deposits, Zagros fold belt, Iran. Ore Geology Reviews, 48, 125-233. DOI: 10.1016/j.oregeorev.2012.02.010

Zarasvandi, A., Zamanian, H. and Hejazi, E.: 2010, Immobile elements and mass changes geochemistry at Sar-Faryab bauxite deposit, Zagros Mountains, Iran. Journal of Geochemical Exploration, 107, No. 1, 7785. DOI: $10.1016 /$ j.gexplo.2010.06.007 